\title{
Developing densified products to reduce transportation costs and improve the quality of rice straw feedstocks for cattle feeding
}

\author{
Phát triển sản phẩm nén từ rơm nhằm giảm chi phí vận chuyển với mục đích sử dụng làm \\ thức ăn trong chăn nuôi
}

\author{
NGUYEN Van Hieu ${ }^{1}$; NGUYEN Thanh Nghi ${ }^{2}$; LE Quang Vinh ${ }^{2}$; LE Minh Anh ${ }^{3}$; NGUYEN Van \\ $\mathrm{Hung}^{4}$; Martin GUMMERT ${ }^{4}$ \\ ${ }^{1}$ Tien Giang University, 119 Ap Bac, Ward 5, My Tho City, Tien Giang Province, Vietnam; ${ }^{2}$ Nong Lam University, Thu Duc District, Ho Chi Minh City, \\ Vietnam; ${ }^{3}$ Binh Minh Group, 784 National Road 50, Cho Gao District, Tien Giang Province, Vietnam; ${ }^{4}$ International Rice Research Institute, DAPO Box \\ 7777, Metro Manila, Philippines
}

\begin{abstract}
Densification of rice straw such as compacting and pelletizing is an important process to increase the density of rice straw resulting in a reduction of transportation cost. Within this research, we conducted a techno-economic investigation of rice straw densification to produce compressed bales and pellets, which are later used for animal feed. In line with the main deliverable of the performance of rice straw compacting and pelletizing processes, we also looked into the quality of the product in terms of uptake and digestibility of the cattle feed which could be improved by adding amendments such as urea during the compacting process. The compacting technology resulted in a $400 \%$ increase of bale density (from 94 to $390 \mathrm{~kg} \cdot \mathrm{m}^{-3}$ ). This could reduce transportation costs by about $60 \%$ for a $60 \mathrm{~km}$ driving distance using trucks. The net profit that resulted from compacted bales was USD $0.0062 \mathrm{~kg}^{-1}$. Although the pelletizing technology increased the cost of the densified product by $40-50 \%$, its density increases by $700 \%$, from 94 to $666 \mathrm{~kg} \cdot \mathrm{m}^{-3}$. The enriched-rice straw pellets contained $12.1 \%$ protein, $2.8 \%$ lipid, $32.7 \%$ raw fibre, and $11.2 \%$ ash. In addition, a test of this product for cattle feeding illustrated an increase in its eating desirability for cows. Findings from this study contribute to reducing feedstock cost and developing densified rice straw products. These, therefore, provide more alternative options to increase the benefits from rice production and thus, reduce the unsustainable burning of rice straw in the field.
\end{abstract}

Nén ép rơm là quá trình quan trọng và cần thiết để tăng khối lượng thể tích với mục đích giảm chi phí vận chuyển. Trong nghiên cứu này, chúng tôi đã thực hiện nghiên cứu đánh giá tính khả thi về kỹ thuật và kinh tế đối với nội dung nén ép rơm cuộn và ép viên rơm. Cùng với mục đích chính là tăng dung trọng của sản phẩm từ rơm, chúng tôi cũng đánh giá chất lượng sản phẩm làm thức ăn cho bò giúp cho tăng kích thích quá trình tiêu hóa. Kết quả nén ép cuộn rơm đã làm tăng dung trọng của kiện rơm đến 400\% (từ 94 đến $398.7 \mathrm{~kg} \cdot \mathrm{m}^{-3}$ ). Qua đó, đã giảm được chi phí vận chuyển 60\% được ước tính cho $60 \mathrm{~km}$ khoảng cách vận chuyển. Đối với ép viên rơm, dung trọng tăng đến 700\% (từ 94 đến 666 kg. $\mathrm{m}^{-3}$ ). Hàm lượng dinh dưỡng của viên nén hỗn hợp rơm gồm protein (12,1\%), chất béo (2,8\%), chất xơ (32,7\%), và lượng tro tổng (11,2\%). Ngoài ra, kết quả thử nghiệm cho bò ăn sản phẩm viên nén này cho thấy bò có cảm giác thích và ăn hết toàn bộ viên nén. Kết quả của nghiên cứu đã góp phần giảm chi phí khi sản xuất thức ăn cho bò, tăng thu nhập cho người nông dân và từ đó giảm tác động môi trường do việc đốt rợm trên đồng.

Keywords: rice straw, densification, pellet, cattle feed, greenhouse gas emission

\section{Introduction}

Rice straw is a by-product of harvesting paddy. In the Mekong Delta of Vietnam, about $90 \%$ of rice field is harvested by a combine harvester. With the use of combine harvester, straw is spread out in the field leading to difficult and tedious work for gathering causing intensives of burning or incorporation of all rice straw in the field. Negative impacts of straw burning and incorporation were reported by Romasanta et al. (2017). For example, burning straw in the open field causes greenhouse gas emission while energy is waste. Nguyen Van Hung et al. (2017) also recommended the better practices of removing rice straw for further alternative uses such as mushroom production and cattle feed. Benefits of off-field rice straw practices for bioenergy was revealed in Nguyen Van Hung et al. (2016a) and Ngo Thi Thanh Truc et al. (2011). However, transportation cost is the main barrier for off-field options of rice straw management. Densification of rice straw such as 
compacting and pelletizing is an important process to increase the density of rice straw resulting in a reduction of transportation cost. With rice straw, densification process can increase its density from $40-100 \mathrm{~kg} \cdot \mathrm{m}^{-3}$ to $600-800$ $\mathrm{kg} \cdot \mathrm{m}^{-3}$ (Kargbo, et al., 2009). Some improvements of rice straw briquetting were revealed in Munder (2008).

In principle, densification includes tumble and pressure agglomeration. Tumble agglomeration includes baling technologies that involved the gathering of rice straw described in a recent research in the same operation (Nguyen Van Hung et al., 2016b). Pressure agglomeration includes extruding, pelletizing, and briquetting.

In Vietnam, a large amount (80\%) of rice straw are burned in the field causing a high environmental foot-print ( $\mathrm{Ngu}$ yen Van Hung et al., 2014). Thanks to the mushroom production business, a straw market has been established since 2003 (Phan Hieu Hien et al., 2013), but it only utilizes a very small amount of the rice straw produced.

In Vietnam, aside from mushroom production, rice straw has been used for cattle feed, as mulch in the cultivation of other crops, and for soil enrichment, etc. However, with an abundant amount of straw in the Mekong Delta, creating a new market for rice straw is a need. Pelletizing technology has been applied to many agricultural by-products. Pelletizing machines are well-known for producing rice husk pellets.

At present, rice husk pellet product is used for combustion energy. Similar to rice husk, rice straw can be pelletized to use for energy purpose. Furthermore, this research also generated a concept of using rice straw pellets for cattle feed.

The objectives of this activity were 1 ) investigation of the rice straw compacting technology based on the density of product and financial benefit, and 2) techno-economic feasibility evaluation of the rice straw pelletizing for cattle feed.

\section{Method}

\subsection{Rice straw compacting experiment}

The experiment was conducted using the compacting system (Fig.1) at Binh Minh Group, Cai Lay Town, Tien Giang Province. The machine compacts the 11 small round straw bales with a density of $87.4 \mathrm{~kg} \cdot \mathrm{m}^{-3}$ into one larger and denser cubic-bale in each batch. Five replications were conducted to investigate the performance parameters such as compacting capacity, power consumption, and compacting density.

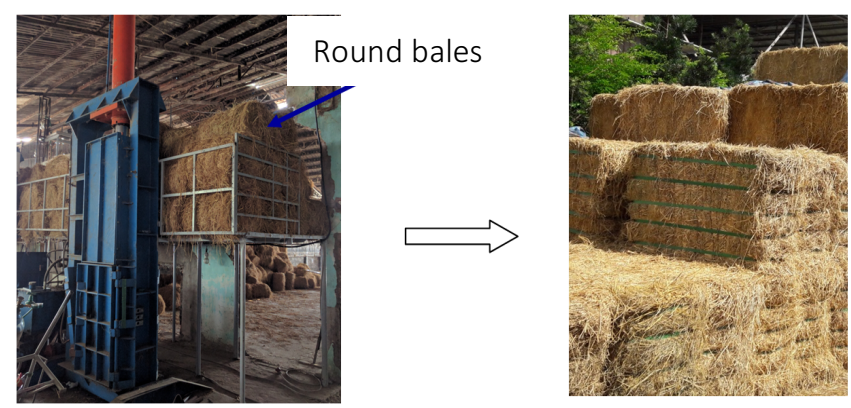

Figure 1. Rice straw compacting

Parameters collected and calculated during the experiment included compacting capacity $\left[\mathrm{kg} \cdot \mathrm{h}^{-1}\right]$, power consumption [ $\left.\mathrm{kWh} . \mathrm{kg}^{-1}\right]$, moisture content of straw and pellets [\%], and temperature of product after pelleting $\left[{ }^{\circ} \mathrm{C}\right]$.

The compacting capacity of each machine was computed based on the actual amount of feeding materials and recorded working time [h]. Power consumption was a ratio of measured power using a three-phase power meter and actual compacting capacity.

Moisture content (MC) of straw was determined using an oven dryer to dry straw samples (30 grams per sample) which were taken during the test. Samples were dried at $105{ }^{\circ} \mathrm{C}$ until constant mass. It is computed by following formula:

in which:

$$
\mathrm{MC}=\frac{\mathrm{G}_{1}-\mathrm{G}_{2}}{\mathrm{G}_{1}}
$$

$M C=$ moisture content,$\%$

$\mathrm{G}_{1}=$ initial mass of sample, $\mathrm{g}$

$\mathrm{G}_{2}=$ final mass of sample, $\mathrm{g}$

The density of straw pellets was determined by the following equation:

$$
\begin{array}{cl}
\rho=\frac{\mathrm{w}}{\mathrm{V}} \\
\text { in which: } \quad \begin{array}{c}
\rho \\
\end{array} \quad \mathrm{density}, \mathrm{kg} \cdot \mathrm{m}^{-3} \\
\mathrm{~W}=\text { mass of straw pellets, } \mathrm{kg} \\
\mathrm{V}=\text { volume of pellets, } \mathrm{m}^{3}
\end{array}
$$

\subsection{Rice straw pelletizing}

Figure 2 shows the process of rice straw pre-treatment and pelletizing investigated in this research. This process includes chopping, grinding, mixing, pelletizing, and packaging.

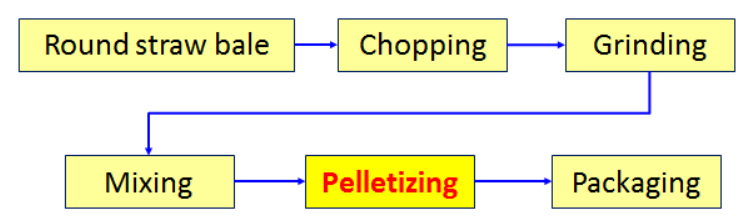

Figure 2. Straw pelletizing process from straw bales

Rice straw is chopped using a rotating chopper shown in Figure 3 . Then, it is fed into a grinding and pelletizing system with its schematic diagram shown in Figure 4. Within 
the experiment, we used the existing rice husk grinder (Figure 5) and pelletizer (Figure 6) for corresponding processing processes of rice straw.

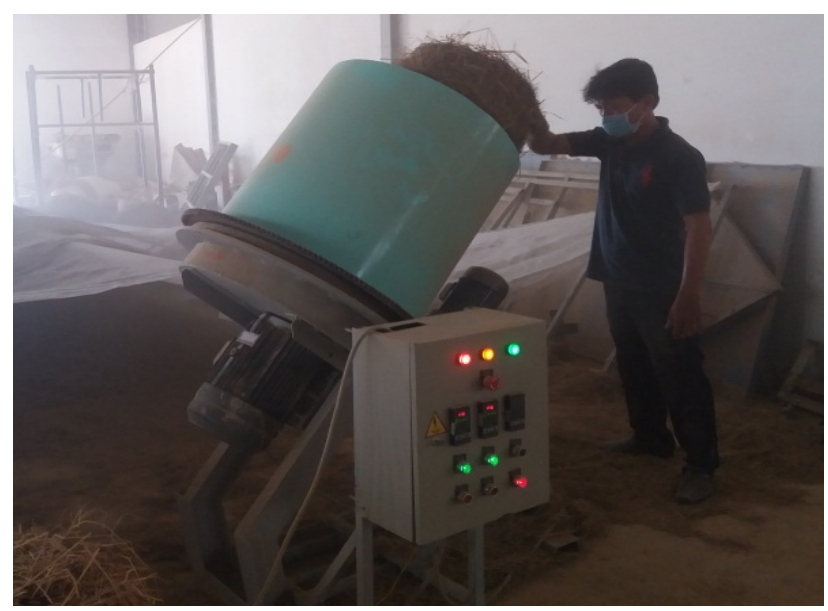

Figure 3. Rice straw rotating chopper

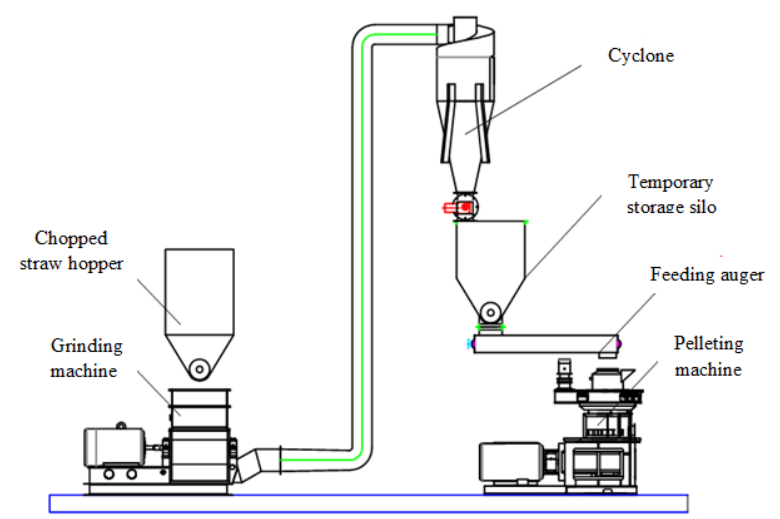

Figure 4. Schematic diagram of pelletizing system

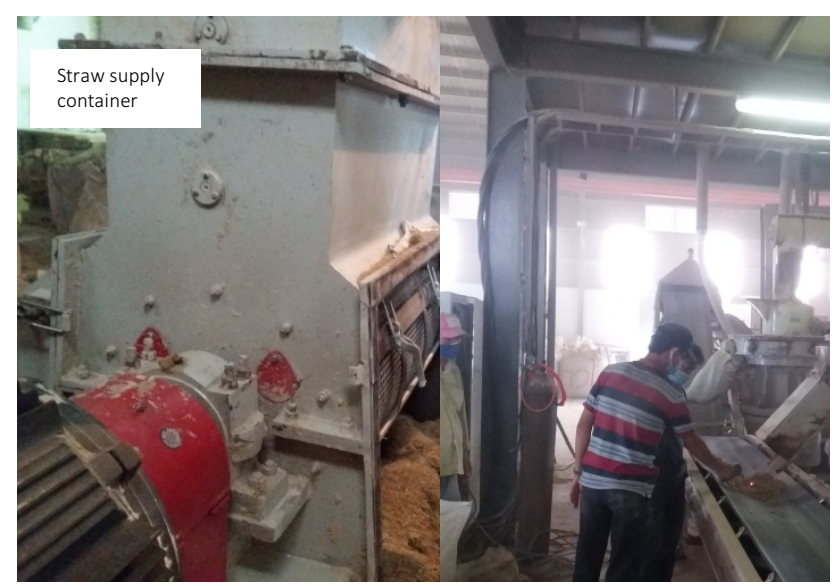

Figure 5. Rice husk grinding machine

Figure 6. Rice husk pelletizing machine

The experiments were conducted with the three treatments of different ratio of feed materials. These feeds were processed by mixing ground rice straw into processed cattle feed. Mass compositions of the materials in each $50 \mathrm{~kg}$-sample is shown in Table 1.

Parameters collected during the experiment included compacting capacity, power consumption, and temperature of the product after pelletizing. The moisture content of straw was determined using an oven dryer to dry straw samples which were taken during the test.

After the pelletizing process, samples of the pellets were randomly taken for nutrient analysis. Parameters for nutrient analysis include protein, lipid, raw fibre, and total ash.

\section{Table 1. Components of materials used in the tests}

\begin{tabular}{clrrr}
\multirow{2}{*}{ No. Components } & \multicolumn{3}{c}{ Treatments } \\
\cline { 3 - 4 } 1 & Ground straw, kg & No.1 & No.2 & No.3 \\
2 & Rice bran, kg & 25 & 30 & 35 \\
3 & Corn meal, kg & 10 & 7.5 & 3.75 \\
4 & Dried soybean oil, kg & 5 & 5 & 3.75 \\
5 & Fish meal (60\%), kg & 4 & 2.5 & 2.5 \\
6 & Bone meal, kg & 3.75 & 2.5 & 2.5 \\
7 & Premix vitamin and minerals, & 2 & 2 & 2.5 \\
& kg & 0.25 & 0.25 & 0.25 \\
8 & Salt, kg & & \\
Total, kg & 0.25 & 0.25 & 0.25 \\
& & 50 & 50 & 50
\end{tabular}

\section{Findings and discussions}

\subsection{Rice straw compacting}

Table 2 shows the results of compacting performance parameters. The machine in one batch compacts 11 round bales into a cubic bale with the dimension of $95 \mathrm{~cm} \times 75 \mathrm{~cm}$ $x 55 \mathrm{~cm}$ and its mass of about $153 \mathrm{~kg}$, corresponding to the density of $398.7 \mathrm{~kg} \cdot \mathrm{m}^{-3}$. With the compacting time of 6 minutes to complete one cubic bale, the compacting capacity is $1530 \mathrm{~kg} \cdot \mathrm{h}^{-1}$. However, including the time for manual unloading of 6 minutes per cubic bale, it has an actual capacity of 5 cubic bales per hour, corresponding to $753.5 \mathrm{~kg} \cdot \mathrm{h}^{-1}$. Specific power consumption is $0.0185 \mathrm{kWh} . \mathrm{kg}^{-1}$ of straw.

\section{Table 2. Test results of cubic baling of 5 replicate samples} Parameters

$\begin{array}{lccccccc} & 1 & 2 & 3 & 4 & 5 & & \\ \text { Moisture content, \% } & 13 & 14 & 14 & 14 & 13 & 13.6 & 0.49\end{array}$ $\begin{array}{llllllll}\text { Mass of cubic bale, kg } \quad 152 & 155 & 157 & 150 & 150 & 152.8 & 2.79\end{array}$ $\begin{array}{llllllll}\text { Compacting } \quad \text { capacity, } 927 & 930 & 942 & 907 & 900 & 921.4 & 15.46\end{array}$ $\mathrm{kg} . \mathrm{h}^{-1}$

$\begin{array}{llllllll}\text { Power consumption, kW } & 16.4 & 18.5 & 17.5 & 16.4 & 16.4 & 17.0 & 0.85\end{array}$

The density of a cubic bale is $398.7 \mathrm{~kg} \cdot \mathrm{m}^{-3}$. The density of the compacted bale is higher by about $400 \%$ than that of the round bales. This technological investigation resulted in the basic parameters for estimating the cost-benefits of the practice. Cost analysis of compacted rice straw results in Table 3. The total compacting (operation) cost is \$US 19 per ton of compacted straw. The total compacted straw bale accounted for cost of in-field straw, collection, and transportation is estimated at \$US 55 per ton of compacted straw. For the present in Vietnam, the compacted straw bale is purchased at 105 \$US/ton generating a net profit of $38 \$ U S /$ ton and the payback is just 0.9-1.1 year. 


\subsection{Rice straw pellets for cattle feed}

Pelleted products are shown in Figure 7 . The length of the straw pellets was in the range of $2-3 \mathrm{~cm}$. The final moisture content (wet basis) of pellets was from 7.53 to $7.97 \%$. The density of the straw pellets was $666 \mathrm{~kg} . \mathrm{m}^{-3}$. In addition, the average specific mass of a straw pellet was identified at $1,244 \mathrm{~kg} . \mathrm{m}^{-3}$, higher by $1000 \%$ than that of loose straw. This product also has another advantage such as preventing straw floating in water in some further processing such as anaerobic digestion.

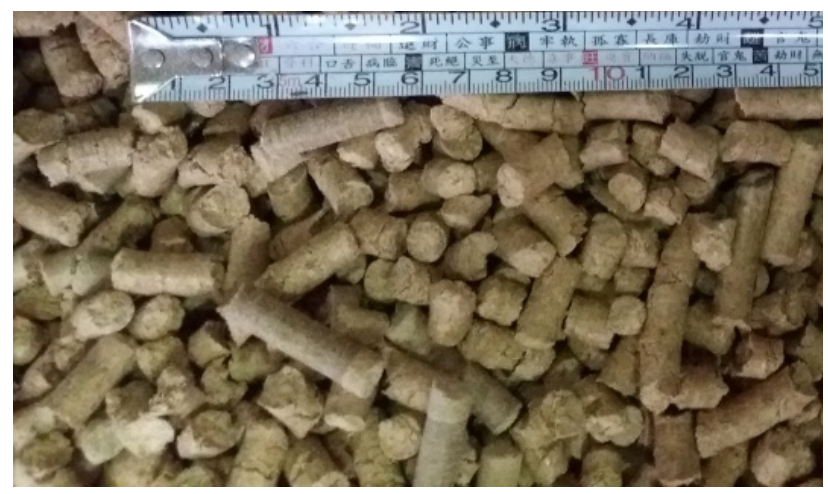

Figure 7. Rice straw pellets

\subsubsection{Cost-benefits of straw pellets}

This was computed based on the estimated cost of equipment, assumed cost of straw and labor at the locality. The total cost of pelletizing included costs of depreciation, materials, and labor. The cost of materials (straw and cattle feed additive) used during the test was USD $280 \mathrm{ton}^{-1}$. The price of straw varied from USD 0.09 to USD $0.1 \mathrm{~kg}^{-1}$. The costs of depreciation, labor, and electricity were estimated based on the existing rice husk pelletizing system. Including the pelletizing cost of USD $0.0226 \mathrm{~kg}^{-1}$, the cost of straw pellets is USD $0.125 \mathrm{~kg}^{-1}$.

A cubic bale is sold at a price of USD $0.11 \mathrm{~kg}^{-1}$, excluding transportation cost. At present, the transportation cost of the cubic bale is about USD $0.0355 \mathrm{~kg}^{-1}$ with a distance of $1000 \mathrm{~km}$ by truck. For grinding straw, the estimated cost is USD $0.1 \mathrm{~kg}^{-1}$.

\subsubsection{Nutrient analysis of straw pellets}

Samples of straw pellets produced from the experiments were analyzed in their nutrient contents shown in Table 3 without loss of nutrient during pelletizing. Highest protein content was in treatment No.1 with 50\% straw and 50\% cattle feed. On the other hand, the highest raw fibre percentage was in treatment No.3 with $70 \%$ straw and $30 \%$ cattle feed. The lowest protein percentage was in treatment No. 2 with $60 \%$ straw and $40 \%$ cattle feed.

These pellet samples were also initially tested to feed cows at Nong Lam University, Ho Chi Minh City (Fig. 8). It was found that the cows ate each of the treatments without leftovers.
Table 3. Test results of the nutrient analysis

\begin{tabular}{lrrr} 
& \multicolumn{3}{c}{ Treatment } \\
\cline { 2 - 4 } Parameters & No.1 & No.2 & No.3 \\
Moisture content, \% & 7.9 & 6.7 & 5.9 \\
Protein, \% & 14.3 & 11.3 & 12.1 \\
Lipid, \% & 3.5 & 3.1 & 2.8 \\
Raw fibre, \% & 27.2 & 26.6 & 32.7 \\
Total ash, \% & 12.1 & 11.8 & 11.2
\end{tabular}

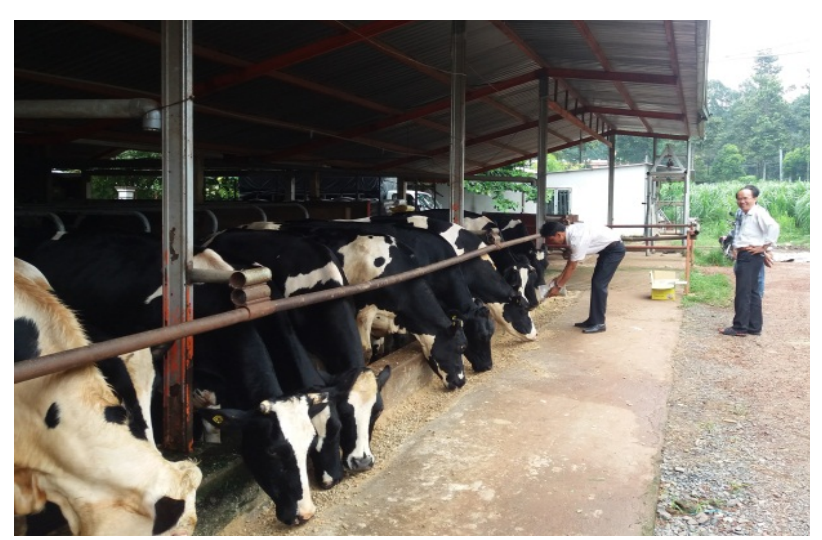

Figure 8. Feeding cattle with straw pellets

\section{Conclusions}

This initial research resulted in the potentials of densification technologies and products. The compacting and pelletizing technology resulted in reducing transportation costs due to increase in its density. The enriched-rice straw pellets were fed the cows without leftovers. The study contributes to creating a new market for rice straw with more alternative options which cause reducing GHG emission from rice straw burning in the field.

Acknowledgements. The authors would thank the German Federal Ministry for Economic Cooperation and Development (BMZ) for its generous funding through the "Scalable straw management options for improved farmer livelihoods, sustainability, and low environmental footprint in rice-based production systems" project (IRRI Ref. No. A2015-48; Contract No. 81194994). The authors also wish to thank all those who supported technical assessment and field test of this study.

\section{References}

[1] Kargbo, F R, J Xing, and Y Zhang. 2009. Pretreatment for Energy Use of Rice Straw: A Review. African Journal of Agricultural Research, 4(13): 1560-1565.

[2] Munder, S. 2013. Improving thermal conversion properties of rice straw by briquetting. Master Thesis. University of Hohenheim.

[3] Ngo Thi Thanh Truc, 2011. Comparative assessment of using rice straw for rapid composting and straw mushroom production in mitigating greenhouse gas emissions in Mekong Delta, Vietnam and Central Luzon, Philippines. Dissertation for PhD in Environmental Science. SESAM, UPLB. 
[4] Nguyen V.H., Carlito B., Quilty J., Bojern S., Demont M., Gummert M., 2017. Processing rice straw and rice husk as co-products, in Achieving sustainable cultivation of rice - 2016 (Vol 2). Burleigh Dodds Science Publishing. Available under: https://shop.bdspublishing.com/checkout/Store/bds/Detail/Product/3-1909781786760289-010

[5] Nguyen, V.H., Topno, S., Balingbing, C., Nguyen, V.C.N., Roder, M., Quilty, J., Jamieson, C., Thornley, P., Gummert, M., 2016a. Generating a positive energy balance from using rice straw for anaerobic digestion. Energy Reports. 2, 117-122.

[6] Nguyen Van Hung, Nguyen Duc Canh, Tran Van Tuan, Hau Duc Hoa, Nguyen Thanh Nghi, Martin Gummert. 2016b. Energy Efficiency, Greenhouse Gas Emissions and Cost of Rice Straw Collection in the Mekong River Delta of Vietnam. Field Crops Research, 198: 16-22.
[7] Nguyen Van Hung, Nguyen Thanh Nghi and Phan Hieu Hien. 2014. Rice Straw Utilization in Vietnam. Technical Report to International Rice Research Institute (IRRI), Nong Lam University, Ho Chi Minh City, Vietnam.

[8] Phan Hieu Hien, and Nguyen Thanh Nghi. 2013. Technology Assessment for Rice Residue Utilization. Technical Report to Netherlands Development Organization (SNV), Nong Lam University, Ho Chi Minh City, Vietnam.

[9] Romasanta, R.R., Sander, B.O., Gaihre, Y.K., Alberto, M.C., Gummert, M., Quilty,J., Nguyen, V.H., Castalone, A.G., Balingbing, C., Sandro, J., Correa,T., Wassmann, R., 2017. How does rice straw burning compare with other straw management practices in terms of on-field $\mathrm{CH}_{4}$ and $\mathrm{N}_{2} \mathrm{O}$ emissions? A comparative field experiment. Agriculture, Ecosystems and Environment, 239: 143-153. 